\title{
Two Salts and the Salt Co-Crystal of Ciprofloxacin with Thiobarbituric and Barbituric acids: the Structure and Properties
}

Nicolay N. Golovnev ${ }^{a}$, Maxim S. Molokeev ${ }^{a, b, c}{ }^{*}$, Maxim K. Lesnikov $^{a}$, Victor V. Atuchin ${ }^{d, e, f, g, h}$

a Siberian Federal University, 79 Svobodny Ave., Krasnoyarsk 660041, Russia

${ }^{b}$ Laboratory of Crystal Physics, Kirensky Institute of Physics, Federal Research Center KSC SB RAS, bld. 38 Akademgorodok 50, Krasnoyarsk 660036, Russia

${ }^{c}$ Department of Physics, Far Eastern State Transport University, 47 Seryshev Str., Khabarovsk 680021, Russia

${ }^{d}$ Laboratory of Optical Materials and Structures, Institute of Semiconductor Physics, SB RAS,

Novosibirsk 630090, Russia

${ }^{e}$ Functional Electronics Laboratory, Tomsk State University, Tomsk 634050, Russia

${ }^{f}$ Laboratory of Semiconductor and Dielectric Materials, Novosibirsk State University, Novosibirsk 630090, Russia

${ }^{g}$ Institute of Chemistry, Tyumen State University, Tyumen 625003, Russia

${ }^{h}$ Laboratory of Single Crystal Growth, South Ural State University, Chelyabinsk 454080, Russia

* Corresponding author:

Maxim Molokeev

E-mail:msmolokeev@gmail.com

Laboratory of Crystal Physics, Kirensky Institute of Physics, SB RAS, bld. 38 Akademgorodok 50, Krasnoyarsk 660036, Russia

Tel.: +7-391-249-45-07

$†$ Electronic supplementary information (ESI) available. See DOI:xxx

\section{Abstract}

Ciprofloxacin $\left(\mathrm{CfH}, \mathrm{C}_{17} \mathrm{H}_{18} \mathrm{FN}_{3} \mathrm{O}_{3}\right)$ crystallizes with 2-thiobarbituric $\left(\mathrm{H}_{2}\right.$ tba) and barbituric acid $\left(\mathrm{H}_{2} \mathrm{ba}\right)$ in the aqueous solution to yield salt $\mathrm{CfH}_{2}(\mathrm{Htba}) \cdot 3 \mathrm{H}_{2} \mathrm{O}$ (1), salt co-crystal $\mathrm{CfH}_{2}(\mathrm{Hba})\left(\mathrm{H}_{2} \mathrm{ba}\right) \cdot 3 \mathrm{H}_{2} \mathrm{O}$ (2) and salt $\mathrm{CfH}_{2}(\mathrm{Hba}) \cdot \mathrm{H}_{2} \mathrm{O}$ (3). The compounds are structurally characterized by the X-ray single-crystal diffraction. The numerous intermolecular hydrogen bonds $\mathrm{N}-\mathrm{H} \cdots \mathrm{O}$ and $\mathrm{O}-\mathrm{H} \cdots \mathrm{O}$, forming of water molecules, $\mathrm{Htba}^{-} / \mathrm{Hba}^{-}$and $\mathrm{CfH}_{2}{ }^{+}$ions, and 
$\mathrm{H}_{2}$ ba molecules stabilize the crystal structures of 1-3. Hydrogen bonds form a 2D plane network in the salts of $\mathbf{1}$ and $\mathbf{3}$, and a 3D network in the salt co-crystal of $\mathbf{2}$. There are different $\pi-\pi$ interactions in 1-3. The compounds have been characterized by powder XRD, TG-DSC and FTIR. The compounds dehydration ends at $130-150{ }^{\circ} \mathrm{C}$, and their oxidative decomposition is observed in the range of $250-275^{\circ} \mathrm{C}$.

Keywords: Thiobarbituric acid; barbituric acid; ciprofloxacin; salts; salt co-crystal; X-ray diffraction; infrared spectroscopy; thermal stability

\section{Introduction}

Fluoroquinolones are one of the most important classes of synthetic antibiotics [1]. However, the molecular mechanism of this enzyme inhibition is still unknown [2, 3]. Ciprofloxacin (CfH), 1-Cyclopropyl-6-fluoro-4-oxo-7(piperazin-1-yl)-1,4-dihydro-3quinolinecarboxylic acid (Fig. 1a) is a widely prescribed broad-spectrum oral fluroquinolone antibiotic [4]. It forms different unstable hydrates [5]. In the aqueous solution, $\mathrm{CfH}$ exists predominantly as a zwitterion (isoelectric point $=7.42$ ). Its intrinsic solubility in water at $25{ }^{\circ} \mathrm{C}$ is comparatively low $c a .0 .08 \mathrm{~g} \cdot l^{-1}$ [6]. One obvious way to increase the aqueous solubility of $\mathrm{CfH}$ is to make a salt [7]. The most common marketed form of $\mathrm{CfH}$ is that of the hydrochloride monohydrate. Evidently, a further search for other ciprofloxacin salts with improved properties is of great practical interest in pharmacology $[8,9]$. Along with the salts, it is possible to use the so-called salt co-crystals $[10,11]$ (or ionic co-crystals, ICCs [12]). The term "salt co-crystal" indicates that a salt, be it inorganic and organic, can co-crystallize with an organic molecule [11]. In a co-crystal, if at least one of coformers is a drug molecule or ion, then it is termed as a pharmaceutical co-crystal [13]. Today, the discovery and exploration of pharmaceutical cocrystals and salts present a major perspective for the controlled modification of key pharmaceutical properties, such as solubility, hydroscopicity, physicochemical stability, photostability and dissolution performance [14].

Barbituric $\left(\mathrm{H}_{2} \mathrm{ba}\right)$ and thiobarbituric $\left(\mathrm{H}_{2}\right.$ tba) acids (Fig. 1b) are the lead structures of 5,5substituted barbiturates and thiobarbiturates, respectively, and they are important groups of sedative/hypnotic drugs [15]. The $\mathrm{Hba}^{-}$and $\mathrm{Htba}^{-}$anions are exceptionally good hydrogen bonding acceptors and donors, which is important for the crystal design of pharmaceuticals and molecular recognition [16]. They can be linked by intermolecular hydrogen bonds to other complementary neutral molecules, for example, such as $\mathrm{H}_{2}$ ba and $\mathrm{H}_{2}$ tba, to form salt co-crystals $[10,17,18]$. Thus, salt co-crystals $\mathrm{M}(\mathrm{Hba})\left(\mathrm{H}_{2} \mathrm{ba}\right) \cdot 2 \mathrm{H}_{2} \mathrm{O}(\mathrm{M}=\mathrm{Na}, \mathrm{K}), \mathrm{K}(\mathrm{Hba})\left(\mathrm{H}_{2} \mathrm{ba}\right)_{0.5} \cdot 1.5 \mathrm{H}_{2} \mathrm{O}$ 
[10] and $\mathrm{Rb}(\mathrm{Hba})\left(\mathrm{H}_{2} \mathrm{ba}\right) \cdot \mathrm{H}_{2} \mathrm{O}$ [17] were previously synthesized. The formation of co-crystals leads to an increase of the $\mathrm{H}_{2}$ ba thermal stability [10]. In the present work, for the first time [19], the structures of compounds formed by fluoroquinolones and barbituric/thiobarbituric acids were solved. The fundamental aim of the present work is to evaluate the solid-state of these compounds. The ciprofloxacinium thiobarbiturate trihydrate, $\mathrm{CfH}_{2}(\mathrm{Htba}) \cdot 3 \mathrm{H}_{2} \mathrm{O} \quad(\mathbf{1})$, ciprofloxacinium 2-thiobarbiturate 2-thiobarbituric acid trihydrate, $\mathrm{CfH}_{2}(\mathrm{Hba})\left(\mathrm{H}_{2} \mathrm{ba}\right) \cdot 3 \mathrm{H}_{2} \mathrm{O}$ (2) and ciprofloxacinium barbiturate monohydrate, $\mathrm{CfH}_{2}(\mathrm{Hba}) \cdot \mathrm{H}_{2} \mathrm{O} \quad$ (3) are synthesized and structurally characterized by the X-ray single-crystal diffraction. Besides, the spectroscopic and thermal properties of 1-3 were observed.

\section{Experimental section}

\subsection{Chemical reagents}

Barbituric acid (CAS 67-52-7) and 2-thiobarbituric acid (CAS 504-17-6) were purchased from Sigma-Aldrich and used without further purification. Ciprofloxacinium chloride monohydrate $\left(\mathrm{CfH} \cdot \mathrm{HCl} \cdot \mathrm{H}_{2} \mathrm{O}\right.$, Ranbaxia, India) was used without further purification.

\subsection{Synthesis}

$0.2 \mathrm{~g}(0.5 \mathrm{mmol})$ of ciprofloxacin hydrochloride monohydrate was dissolved in $5 \mathrm{ml}$ of water, then $0.074 \mathrm{~g}(0.5 \mathrm{mmol}) \mathrm{H}_{2}$ tba and $0.02 \mathrm{~g}(0.5 \mathrm{mmol}) \mathrm{NaOH}$ were added. The resulting mixture was heated to $80^{\circ} \mathrm{C}$ and held at this temperature for $30 \mathrm{~min}$. The pale yellow bulk precipitate formed in the solution was filtered off and discarded as it consists of a mixture of several phases. The hot filtrate $(\mathrm{pH} 4)$ was cooled to room temperature and held at $3{ }^{\circ} \mathrm{C}$ for two days. The formed pale yellow crystal precipitate of $\mathrm{CfH}_{2}(\mathrm{Htba}) \cdot 3 \mathrm{H}_{2} \mathrm{O}(\mathbf{1})$ was filtered, washed with water $(1 \mathrm{ml})$, acetone and dried in the air (yield $30 \%)$.

The synthesis of $\mathrm{CfH}_{2}(\mathrm{Hba}) \cdot \mathrm{H}_{2} \mathrm{O}(\mathbf{3})$ was performed similar to the synthesis of $\mathbf{1}$, except for an equimolar amount of $\mathrm{H}_{2}$ ba $(0.064 \mathrm{~g}, 0.5 \mathrm{mmol})$ used instead of $\mathrm{H}_{2}$ tba. After dissolving all the reagents at $80^{\circ} \mathrm{C}$, the solution was slowly cooled to room temperature $(\mathrm{pH} 4.6)$ and, then, the resulting colourless crystalline precipitate was filtered off, washed with water $(1 \mathrm{ml})$, acetone and air-dried (yield 58\%).

Compound $\mathrm{CfH}_{2}(\mathrm{Hba})\left(\mathrm{H}_{2} \mathrm{ba}\right) \cdot 3 \mathrm{H}_{2} \mathrm{O}$ (2) was obtained under similar conditions, except for that the double excess of $\mathrm{H}_{2} \mathrm{ba}(0.128 \mathrm{~g}, 1.0 \mathrm{mmol})$ was used. After dissolving all the reagents at $80^{\circ} \mathrm{C}$, the solution was slowly cooled to room temperature $(\mathrm{pH} 4.0)$ and then stored at $2^{\circ} \mathrm{C}$ for 24 h. The resulting pale yellow crystalline precipitate was filtered off, washed with water $(1 \mathrm{ml})$, acetone and air-dried (yield 60\%). 
The elemental analysis for $\mathrm{C}_{21} \mathrm{H}_{28} \mathrm{FN}_{5} \mathrm{O}_{8} \mathrm{~S}$ (1): Calc.: C, 47.6\%; H, 5.33\%; N, 13.2\%; $\mathrm{S}$, 6.06. Found: C, $47.2 \% ; \mathrm{H}, 5.52 \% ; \mathrm{N}, 12.9 \% ; \mathrm{S}, 6.21 \%$. The elemental analysis for $\mathrm{C}_{25} \mathrm{H}_{32} \mathrm{FN}_{7} \mathrm{O}_{12}$ (2): Calc.: C, 46.8\%; H, 5.03\%; N, 15.3\%. Found: C, 46.2\%; H, 5.22\%; N, 15.0\%. The elemental analysis for $\mathrm{C}_{21} \mathrm{H}_{24} \mathrm{FN}_{5} \mathrm{O}_{7}$ (3): Calc.: C, 52.8\%; H, 5.07\%; N, 14.7\%. Found: C, 52.2\%; H, $5.24 \% ; \mathrm{N}, 14.5 \%$.

The single crystals suitable for a structural analysis were selected directly from the total mass of precipitates 1-3. The powder patterns of 1-3, simulated from the single crystal structural data, well agree to the measured ones (Figs. 1S, 2S, 3S) indicating that the corresponding crystal structures represent the bulk structures.

\subsection{X-ray diffraction analysis}

The intensity patterns were collected from single crystals 1-3 using the SMART APEX II diffractometer (Bruker AXS) equipped with a CCD-detector, graphite monochromator and Mo$\mathrm{K} \alpha$ radiation source. The absorption corrections were applied using the SADABS program. The structures were solved by the direct methods using package SHELXS and refined in the anisotropic approach for non-hydrogen atoms using the SHELXL program [20]. All hydrogen atoms were found via Fourier difference maps. Further, the hydrogen atoms which are linked with $\mathrm{C}, \mathrm{N}$ atoms in the $\mathrm{Htba}^{-}$and $\mathrm{CfH}_{2}{ }^{+}$ions in $\mathbf{1}$ and $\mathbf{2}$ were positioned geometrically as riding on their parent atoms with $\mathrm{d}(\mathrm{C}-\mathrm{H})=0.93-0.98 \AA, \mathrm{d}(\mathrm{N}-\mathrm{H})=0.86-0.89 \AA$ depending on the geometry and $\mathrm{U}_{\mathrm{iso}}(\mathrm{H})=1.2 \mathrm{U}_{\mathrm{eq}}(\mathrm{C}, \mathrm{N})$. All hydrogen atoms of the $\mathrm{H}_{2} \mathrm{O}$ molecules and one $\mathrm{H}$ atom in the $\mathrm{OH}$ group of $\mathrm{CfH}_{2}{ }^{+}$ion were refined with bond length restraint $\mathrm{d}(\mathrm{O}-\mathrm{H})=0.9 \AA$ and $\mathrm{U}_{\text {iso }}(\mathrm{H})$ $=1.2 \mathrm{U}_{\mathrm{eq}}(\mathrm{O})$. The structure test for the presence of missing symmetry elements and possible voids was produced using program PLATON [21]. The DIAMOND program is used for the crystal structure plotting [22].

The powder X-ray diffraction data were obtained using diffractometer D8 ADVANCE (Bruker) equipped by a VANTEC detector with a Ni filter. The measurements were made using $\mathrm{Cu} \mathrm{K} \alpha$ radiation. The structural parameters defined by single crystal analysis were used as a base in the powder pattern Rietveld refinement.

\subsection{Physical measurements}

TGA was carried out on the simultaneous SDT-Q600 thermal analyzer (TA Instruments, USA) under the dynamic air atmosphere $\left(50 \mathrm{ml} / \mathrm{min}\right.$ flow rate) within $25-350{ }^{\circ} \mathrm{C}$ at the scan rate of $10{ }^{\circ} \mathrm{C} / \mathrm{min}$. The qualitative composition of the evolved gases was determined by FT-IR spectrometer Nicolet380 (Thermo Scientific, USA) combined with a thermal analyzer and with the TGA/FT-IR interface (attachment for the gas phase analysis). This set up allows making a 
simultaneous accumulation of the DTA and TG data, and the composition of the released gas phase. The compound weight was $6.442 \mathrm{mg}$ for $\mathbf{1}, 8.433 \mathrm{mg}$ for 2 and $4.442 \mathrm{mg}$ for $\mathbf{3}$. Platinum crucibles with perforated lids were used as the containers. The IR absorption spectra of the compounds inserted into the $\mathrm{KBr}$ tablets were recorded over the range of $400-4000 \mathrm{~cm}^{-1}$ at room temperature on an FT-IR spectrometer Nicolet 6700 (Thermo Scientific, USA, SFU CEJU).

\section{Results and discussion}

\subsection{Crystal structures of 1}

The unit cell of $\mathrm{CfH}_{2}{ }^{+}\left(\mathrm{Htba}^{-}\right) \cdot 3 \mathrm{H}_{2} \mathrm{O}$ corresponds to the triclinic symmetry. Space group $P-1$ was determined from the statistical analysis of the reflection intensities. The main crystal data are shown in Table 1 . The corresponding bond lengths $\mathrm{C}-\mathrm{O}, \mathrm{C}-\mathrm{S}, \mathrm{C}-\mathrm{N}, \mathrm{C}-\mathrm{C}$ and valence angles in the $\mathrm{CfH}_{2}{ }^{+}$cation and $\mathrm{Htba}^{-}$anion (Table 1S) well related to those found earlier for other compounds $[8,9,19,23-31]$. The independent part of the unit cell contains one $\mathrm{CfH}_{2}{ }^{+}$ion, one $\mathrm{Htba}^{-}$ion and three $\mathrm{H}_{2} \mathrm{O}$ molecules (Fig. 2a). There are two intramolecular hydrogen bonds $\mathrm{C}-\mathrm{H} \cdots \mathrm{F}, \mathrm{O}-\mathrm{H} \cdots \mathrm{O}$ and ten intermolecular hydrogen bonds $\mathrm{N}-\mathrm{H} \cdots \mathrm{O}$ and $\mathrm{O}-\mathrm{H} \cdots \mathrm{O}$ in structure 1 (Fig. 3a, Table 2) which form the 2D plane network. This is a 5-nodal net with stoichiometry $(3-c)(3-c)(3-c)(4-c)(5-c)$ and with the vertex symbol $\left(4.5^{2} .6^{2} .7\right)\left(4.5^{4} .6 .7^{3} .8\right)(5.6 .7)(5.6 .9)\left(5^{2} .7\right)$, which is new [32]. Hydrogen bonds form two alternating infinite chains, one of them consists of $\mathrm{CfH}_{2}{ }^{+}$ions bound by water molecules; the second one consists of $\mathrm{Htba}^{-}$ions and water molecules (Figure 3a). Each $\mathrm{CfH}_{2}{ }^{+}$ion in the chain forms H-bonds with two water molecules, while the sequence of molecules is $\mathrm{CfH}_{2}{ }^{+} \cdots \mathrm{H}_{2} \mathrm{O} \cdots \mathrm{CfH}_{2}{ }^{+} \cdots \mathrm{H}_{2} \mathrm{O}$. When the $\mathrm{CfH}_{2}{ }^{+}$ion interacts with one water molecule $\mathrm{H}_{2}(\mathrm{O} 1 \mathrm{~W})$, the piperazin-1-yl $\mathrm{N}$ atom of $\mathrm{NH}_{2}{ }^{+}$group is the $\mathrm{H}$-bond donor $(\mathrm{N} 1-\mathrm{H} \cdots \mathrm{O} 1 \mathrm{~W})$, but when the $\mathrm{CfH}_{2}{ }^{+}$ ion interacts with another water molecule $\mathrm{H}_{2}(\mathrm{O} 2 \mathrm{~W})$, the $\mathrm{O} 2$ atom is the $\mathrm{H}$-bond acceptor $(\mathrm{H}-$ bond $\mathrm{O} 2 \mathrm{~W}-\mathrm{H} \cdots \mathrm{O} 2$ ). Htba-ions are combined together by hydrogen bonds $\mathrm{N}-\mathrm{H} \cdots \mathrm{O}$ into pairs with the formation of supramolecular motif $\mathrm{R}_{2}{ }^{2}(8)$, which is often found in other thiobarbiturate compounds [23-30]. These pairs are connected together by H-bonds with the participation of two water molecules (cyclic motif $\mathrm{R}_{4}^{2}(8)$ ) and that results in the formation of an infinite chain. The interesting ring supramolecular motifs in this network are formed by the hydrogen bonds between ions $\mathrm{CfH}_{2}{ }^{+}$and $\mathrm{Htba}^{-}\left(\mathrm{R}_{5}{ }^{5}(14), \mathrm{R}_{6}{ }^{5}(27)\right)$ (Fig. 3a). Also, there are $\pi-\pi$ interactions between $\mathrm{Htba}^{-}$and $\mathrm{CfH}_{2}{ }^{+}$rings (Table $2 \mathrm{~S}$, Fig. $4 \mathrm{Sa}$ ). $\mathrm{CfH}_{2}{ }^{+}$ions are connected in pairs by the $\pi-\pi$ interaction of head-to-tail type.

\subsection{Crystal structure of 2}


Compound $\mathrm{CfH}_{2}(\mathrm{Hba})\left(\mathrm{H}_{2} \mathrm{ba}\right) \cdot 3 \mathrm{H}_{2} \mathrm{O}$ (2) is a pharmaceutical co-crystal [13]. The unit cell of $\mathrm{CfH}_{2}(\mathrm{Hba})\left(\mathrm{H}_{2} \mathrm{ba}\right) \cdot 3 \mathrm{H}_{2} \mathrm{O}$ (2) also corresponds to the triclinic symmetry. Space group $P-1$ was determined from the statistical analysis of the reflection intensities. The main crystal data can be found in Table 1. The main bond lengths $\mathrm{C}-\mathrm{O}, \mathrm{C}-\mathrm{N}, \mathrm{C}-\mathrm{C}$ and valence angles are enumerated in Table 1S. They coincide with those given in the literature for the $\mathrm{CfH}_{2}{ }^{+}[8,9,19]$ and uncoordinated $\mathrm{Hba}^{-}$ions [33-36]. The main geometric parameters of $\mathrm{H}_{2}$ ba in 2 coincided with those found in the free keto form $\mathrm{H}_{2}$ ba [37] and co-crystals [10, 17]. The independent part of the unit cell contains one $\mathrm{CfH}_{2}{ }^{+}$ion, one $\mathrm{Hba}^{-}$ion (A), one $\mathrm{H}_{2}$ ba (B) molecule and three $\mathrm{H}_{2} \mathrm{O}$ molecules (Fig. 2b). There are two intramolecular hydrogen bonds $\mathrm{C}-\mathrm{H} \cdots \mathrm{F}, \mathrm{O}-\mathrm{H} \cdots \mathrm{O}$ and twelve intermolecular hydrogen bonds $\mathrm{N}-\mathrm{H} \cdots \mathrm{O}, \mathrm{O}-\mathrm{H} \cdots \mathrm{O}$ in the structure (Fig. 3b, Table 2) which form a 3D network. This is a 4-nodal net with stoichiometry (3-c)(3-c)(3-c)2(5-c) and point symbol $(4.5 .6)_{2}\left(5.6^{2}\right)\left(5^{2} \cdot 6^{3} .8 .9^{4}\right)\left(6.10^{2}\right)$, which is also new [32]. Intermolecular hydrogen bonds $\mathrm{N}-\mathrm{H}$...O form the chain of alternating $\mathrm{Hba}^{-}$and $\mathrm{H}_{2}$ ba in the keto form based on the $\mathrm{R}_{2}{ }^{2}(8)$ pattern. In compounds $\mathrm{Rb}(\mathrm{Hba})\left(\mathrm{H}_{2} \mathrm{ba}\right) \cdot 3 \mathrm{H}_{2} \mathrm{O}$ [17] and $\mathrm{M}(\mathrm{Hba})\left(\mathrm{H}_{2} \mathrm{ba}\right) \cdot 3 \mathrm{H}_{2} \mathrm{O}(\mathrm{M}=\mathrm{Na}, \mathrm{K})$ [10], the chains with sequence $\mathrm{H}_{2} \mathrm{ba}^{\cdots} \mathrm{Hba}^{-} \cdots \mathrm{H}_{2} \mathrm{ba}^{\cdots} \cdots \mathrm{Hba}^{-}$.also are formed. However, in $\mathrm{K}(\mathrm{Hba})\left(\mathrm{H}_{2} \mathrm{ba}\right)_{0.5} \cdot 1.5 \mathrm{H}_{2} \mathrm{O}$, sequence $\mathrm{H}_{2} \mathrm{ba}^{\cdots} \cdot \mathrm{Hba}^{-} \cdots \mathrm{Hba}^{-} \cdots \mathrm{H}_{2} \mathrm{ba}$ is observed [10]. Salt co-crystals $\mathrm{MBr} \cdot \mathrm{H}_{2}$ ba $(\mathrm{M}=\mathrm{Rb}, \mathrm{Cs})$ and $\mathrm{CsI} \cdot \mathrm{H}_{2}$ ba are characterized by the presence of $\mathrm{H}_{2}$ ba dimers linked via $\mathrm{N}-\mathrm{H} \cdots \mathrm{O}$ hydrogen bonds [38]. Dimeric fragment $\mathrm{H}_{2} \mathrm{tba}^{\cdots} \mathrm{Htba}^{-}$was observed in the salt cocrystal of piperidinium $\left(\mathrm{PipeH}^{+}\right)$2-thiobarbiturate and 2-thiobarbituric acid, $\mathrm{PipeH}(\mathrm{Htba}) \mathrm{H}_{2} \mathrm{tba}$ [18]. In 2, two water molecules joint $\mathrm{CfH}_{2}{ }^{+}$ions in pairs by hydrogen bonds $\mathrm{O}-\mathrm{H} \cdots \mathrm{O}$ forming a 16-membered ring $\left(\mathrm{R}_{6}{ }^{4}(16)\right)$. Hydrogen bonds $\mathrm{OW}-\mathrm{H} \cdots \mathrm{OW}$ ' atract four water molecules (motif $\mathrm{R}_{4}{ }^{4}(8)$ ) in the cycle, three of which are bound by hydrogen bonds $\mathrm{OW}-\mathrm{H} \cdots \mathrm{O} 3 \mathrm{~A}$ with three Hba(A) ions, forming two bound infinite chains $\cdots \mathrm{Hba}^{-} \cdots \mathrm{H}_{2} \mathrm{ba}^{\cdots} \mathrm{Hba}^{-} \cdots \mathrm{H}_{2} \mathrm{ba} \cdots$ (Fig. 3b). $\mathrm{CfH}_{2}{ }^{+}$ions are also combined into pairs by intermolecular hydrogen bonds $\mathrm{OW}-\mathrm{H} . . \mathrm{O}$ with the participation of just two water molecules. Each $\mathrm{CfH}_{2}{ }^{+}$ion is bound to $\mathrm{Hba}^{-}$or $\mathrm{H}_{2}$ ba by a single hydrogen bond $\mathrm{N} 1-\mathrm{H} \cdots \mathrm{O}$ (Table 2). The hydrogen bonds involving $\mathrm{Hba}^{-}$ions, $\mathrm{H}_{2} \mathrm{ba}$ and $\mathrm{H}_{2} \mathrm{O}$ molecules also form other cyclic motifs in this network $\mathrm{R}_{4}^{4}(8), \mathrm{R}_{5}{ }^{4}(14)$ and $\mathrm{R}_{6}{ }^{6}(20)$ (Fig. 3b). There are $\pi-\pi$ interactions between $\mathrm{Hba}^{-}$and $\mathrm{CfH}_{2}{ }^{+}$rings in 2. Like in 1, two $\mathrm{CfH}_{2}{ }^{+}$form the pairs in $\mathbf{2}$ (Table 2S, Fig. 4Sb).

\subsection{Crystal structure of (3) and comparison}

The unit cell of $\mathrm{CfH}_{2}(\mathrm{Hba}) \cdot \mathrm{H}_{2} \mathrm{O}(3)$ corresponds to the monoclinic symmetry. Space group $P 2_{1} / \mathrm{c}$ was determined from the extinction rules and statistical analysis of the reflection intensities. The main crystal data are summarized in Table 1. The main defined bond lengths and valence angles are shown in Table 1S. They relate well to those found in $\mathbf{2}$ and in the literature 
for the $\mathrm{CfH}_{2}{ }^{+}[8,9,19]$ and $\mathrm{Htba}^{-}$ions [33-36]. The independent part of the unit cell contains one $\mathrm{CfH}^{+}$ion, one $\mathrm{Hba}^{-}$ion and one $\mathrm{H}_{2} \mathrm{O}$ molecule (Fig. 2c). There are two intramolecular hydrogen bonds $\mathrm{C}-\mathrm{H} \cdots \mathrm{F}, \mathrm{O}-\mathrm{H} \cdots \mathrm{O}$ and five intermolecular hydrogen bonds $\mathrm{N}-\mathrm{H} \cdots \mathrm{O}, \mathrm{O}-\mathrm{H} \cdots \mathrm{O}$ in the structure (Fig. 3c, Table 2), which form a 2D network.

$\mathrm{Hba}^{-}$ions are connected to each other by two hydrogen bonds $\mathrm{N}-\mathrm{H} \cdots \mathrm{O}$, closing the 8membered ring $\left(\mathrm{R}_{2}^{2}(8)\right)$. As a result, they form their infinite chains along the $a$-axis. With the help of $\mathrm{H}$-bonds $\mathrm{N} 1-\mathrm{H} \cdots \mathrm{O}$ and $\mathrm{O}-\mathrm{H} \cdots \mathrm{O}$, these infinite chains of $\mathrm{Hba}^{-}$ions are joined together by other chains containing one ion $\mathrm{CfH}_{2}{ }^{+}, \mathrm{H}_{2} \mathrm{O}$ and $\mathrm{Hba}^{-}$. The $\mathrm{H}$-bond donor is the positively charged piperazinium $\mathrm{N} 1$ atom in $\mathrm{CfH}_{2}{ }^{+}$, which directly joints $\mathrm{CfH}_{2}{ }^{+}$and $\mathrm{Hba}^{-}$using $\mathrm{H}$-bond $\mathrm{N} 1-\mathrm{H} \cdots \mathrm{O} 2 \mathrm{~A}$. The acceptor $\mathrm{O} 3$ atom of $\mathrm{CfH}_{2}{ }^{+}$carboxyl group is attracted by $\mathrm{H}$-bond $\mathrm{O} 1 \mathrm{~W}-$

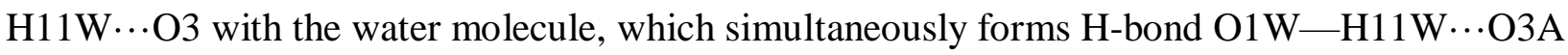
with $\mathrm{Hba}^{-}$. This is a 2-nodal net with stoichiometry $(2-\mathrm{c})_{2}(4-\mathrm{c})$ and point symbol $\left(6.10^{5}\right)(6)_{2}$, which is also new [32]. There are two most interesting motifs in this network: $\mathrm{R}_{2}^{2}(8)$ and $\mathrm{R}_{10}{ }^{9}(52)$ (Fig. 3c). Also, there are $\pi-\pi$ interactions between the two rings of $\mathrm{CfH}_{2}{ }^{+}$(Table $2 \mathrm{~S}$, Fig. $4 S)$.

It is possible to point out the similarity in the structure of the compounds under study. Water molecules stabilize crystal structures 1-3 by forming a diverse arrangement of supramolecular heterosynthons (Fig. 3). There are two intramolecular hydrogen bonds $\mathrm{C}-\mathrm{H} \cdots \mathrm{F}, \mathrm{O}-\mathrm{H} \cdots \mathrm{O}$ in $\mathbf{1 -}$ 3 (Fig. 2). The carbonyl and carboxyl groups of $\mathrm{CfH}_{2}{ }^{+}$are involved in a strong intramolecular $\mathrm{O} 3-\mathrm{H} \cdots \mathrm{O} 1$ hydrogen bond and, therefore, the $\mathrm{O} 3-\mathrm{H}$ group does not participate in the formation of intermolecular hydrogen bonds. This limits the possibility of fluoroquinolones selfassociation, for example, in 1-3, $\mathrm{CfH}_{2}{ }^{+}$cations are not directly related to each other. In $\mathbf{2}$ and $\mathbf{3}$, the $\mathrm{CfH}_{2}{ }^{+}$ions are bound to $\mathrm{Hba}$ or $\mathrm{H}_{2}$ ba by hydrogen bond $\mathrm{N} 1-\mathrm{H}$... (Table 2), but in $\mathbf{1}, \mathrm{CfH}_{2}{ }^{+}$ ions are bound to $\mathrm{Htba}^{-}$through bridging water molecules. Compounds 1-3 possess very similar bond lengths $\mathrm{O}-\mathrm{C}, \mathrm{C} 4-\mathrm{C} 5$, and $\mathrm{C} 5-\mathrm{C} 6$ in the $\mathrm{O}=\mathrm{C}_{4}-\mathrm{C}_{5} \mathrm{H}-\mathrm{C}_{6}=\mathrm{O}$ group (Fig. 2, Table 1S), and that indicates the formation of the $\mathrm{Hba}^{-}$and $\mathrm{Htba}^{-}$anions accompanied by the charge delocalization. Earlier, such delocalization was observed in other 2-thiobarbiturates [23-31] and 1,3-diethyl-2-thiobarbiturates [39-43]. Structures 1-3 are stabilized by $\pi-\pi$ interactions between $\mathrm{CfH}_{2}{ }^{+}$ions of the head-to-tail type. These interactions connect $\mathrm{CfH}_{2}{ }^{+}$ions in pairs in structures 13 (Table 2S, Fig. 4S). Also, there are $\pi-\pi$ interactions between $\mathrm{Htba}^{-} / \mathrm{Hba}^{-}$and $\mathrm{CfH}_{2}{ }^{+}$ions in 1-2.

\subsection{Theoretical consideration}


It is generally accepted that the reaction of an acid (in our case $\mathrm{H}_{2}$ tba and $\mathrm{H}_{2}$ ba) with a base $(\mathrm{CfH})$ is expected to form a salt if $\Delta \mathrm{pK}_{\mathrm{a}}=\mathrm{pK}_{\mathrm{a}}$ (base) $-\mathrm{pK}_{\mathrm{a}}$ (acid) $>2$ or 3 [44]. In spite of that the $\mathrm{pK}_{\mathrm{a}}$ value describes equilibrium phenomena in the solution, it remains to be a useful method for the prediction of the ionization state in crystals [44].

$$
\begin{aligned}
& \mathrm{CfH}_{2}{ }^{+} \leftrightarrow \mathrm{CfH}+\mathrm{H}^{+} \quad \mathrm{pK}_{\mathrm{a}}=6.05[45] \\
& \mathrm{H}_{2} \mathrm{tba} \leftrightarrow \mathrm{Htba}^{-}+\mathrm{H}^{+} \quad \mathrm{pK}_{\mathrm{a}}=1.87[46] \\
& \mathrm{H}_{2} \mathrm{ba} \leftrightarrow \mathrm{Htba}^{-}+\mathrm{H}^{+} \quad \mathrm{pK}_{\mathrm{a}}=4.03[47] \\
& \text { For reaction } \mathrm{H}_{2} \mathrm{tba}+\mathrm{CfH} \leftrightarrow \mathrm{Htba}^{-}+\mathrm{CfH}_{2}^{+} \\
& \mathrm{K}_{\mathrm{eq}}=\left[\mathrm{Htba}^{-}\right]\left[\mathrm{CfH}_{2}^{+}\right] /\left[\mathrm{H}_{2} \mathrm{tba}\right][\mathrm{CfH}]=10^{6.05} / 10^{1.87}=10^{4.18} \approx 1.51 \cdot 10^{4} .
\end{aligned}
$$

Therefore, the concentration of ionized species will be $1.51 \cdot 10^{4}$ times greater that the concentration of non-ionized species in an aqueous solution, containing the equimolar amounts of $\mathrm{CfH}$ and $\mathrm{H}_{2}$ tba. The salt formation of $\mathbf{1}$ is consistent with the $\Delta \mathrm{pK}_{\mathrm{a}}$ rule.

$$
\begin{aligned}
& \text { For reaction } \mathrm{H}_{2} \mathrm{ba}+\mathrm{CfH} \leftrightarrow \mathrm{Hba}^{-}+\mathrm{CfH}_{2}{ }^{+} \\
& \mathrm{K}_{\mathrm{eq}}=\left[\mathrm{Hba}^{-}\right]\left[\mathrm{CfH}_{2}{ }^{+}\right] /\left[\mathrm{H}_{2} \mathrm{ba}\right][\mathrm{CfH}]=10^{6.05} / 10^{4.03}=10^{2.02} \approx 105 .
\end{aligned}
$$

In the aqueous solution, containing the equimolar amounts of $\mathrm{CfH}$ and $\mathrm{H}_{2}$ ba, the $\Delta \mathrm{pK}_{\mathrm{a}}$ value for the interaction between $\mathrm{CfH}_{2}{ }^{+}$and $\mathrm{H}_{2}$ ba is 2.02 which is also preferable for the formation of salt 3. However, at molar ratio $\mathrm{CfH}: \mathrm{H}_{2} \mathrm{ba}=1: 2(\mathrm{pH} 4)$, the ionized and non-ionized $\mathrm{H}_{2}$ ba species are coexisted in approximately equal concentrations. Thus, a favorable condition appears for the crystallization of phase 2, containing $\mathrm{H}_{2}$ ba molecules and $\mathrm{Hba}^{-}$anions together. The $\mathrm{C}-\mathrm{O}$ distances $(\mathrm{d}(\mathrm{O} 1 \mathrm{~A}-\mathrm{C} 2 \mathrm{~A})=1.235(2) \AA, \mathrm{d}(\mathrm{O} 2 \mathrm{~A}-\mathrm{C} 4 \mathrm{~A})=1.265(2) \AA, \mathrm{d}(\mathrm{O} 3 \mathrm{~A}-\mathrm{C} 6 \mathrm{~A})=1.265(2)$ $\AA$ in the $\mathrm{Hba}^{-}$ion (A) (Table $1 \mathrm{~S}$ ) are greater than the $\mathrm{C}-\mathrm{O}$ distances in the un-ionized trioxo form of $\mathrm{H}_{2}$ ba [37]. The $\mathrm{C}-\mathrm{O}$ distances $(\mathrm{d}(\mathrm{O} 1 \mathrm{~B}-\mathrm{C} 2 \mathrm{~B})=1.218(2) \AA$ $\AA, \mathrm{d}(\mathrm{O} 3 \mathrm{~B}-\mathrm{C} 6 \mathrm{~B})=1.206(2) \AA$ in the $\mathrm{H}_{2}$ ba (B) molecule coincide with the distances of $\mathrm{C}-\mathrm{O}$ in the molecular trioxo form of $\mathrm{H}_{2}$ ba. A similar difference between the lengths of the $\mathrm{C}-\mathrm{O}$ bonds in the $\mathrm{Hba}^{-}$ion and the $\mathrm{H}_{2}$ ba molecule was found in other salt co-crystals. For example, $\mathrm{d}(\mathrm{O}-\mathrm{C})$ of $\mathrm{H}_{2}$ ba in salt co-crystals $\mathrm{Rb}(\mathrm{Hba})\left(\mathrm{H}_{2} \mathrm{ba}\right) \cdot 3 \mathrm{H}_{2} \mathrm{O}$ [17], $\mathrm{M}(\mathrm{Hba})\left(\mathrm{H}_{2} \mathrm{ba}\right) \cdot 3 \mathrm{H}_{2} \mathrm{O}(\mathrm{M}=\mathrm{Na}, \mathrm{K})$, $\mathrm{K}(\mathrm{Hba})\left(\mathrm{H}_{2} \mathrm{ba}\right)_{0.5} \cdot 1.5 \mathrm{H}_{2} \mathrm{O}$ [10], $\mathrm{MBr} \cdot \mathrm{H}_{2}$ ba $(\mathrm{M}=\mathrm{Rb}, \mathrm{Cs})$ and $\mathrm{CsI} \cdot \mathrm{H}_{2}$ ba [38] are in the range of 1.21-1.22 $\AA$, but these values of $\mathrm{Hba}^{-}$are bigger and they are in the range of 1.23-1.27 $\AA$. The distances $\mathrm{O}-\mathrm{C}$ in the trioxo form of detached $\mathrm{H}_{2}$ ba (1.21-1.22 $\AA$ ) [37] are similar to those in the above mentioned co-crystals and compounds $\left[\mathrm{Ca}\left(\mu_{3}-\mathrm{H}_{2}\right.\right.$ ba- $\left.\left.-\mathrm{O}, \mathrm{O}^{\prime}, \mathrm{O}^{\prime \prime}\right)\right] \mathrm{X}_{2}(\mathrm{X}=\mathrm{Cl}[12], \mathrm{I}[48])$. 
The equilibrium equation for solubility $\mathbf{2}$ has the form:

$$
\mathrm{CfH}_{2}(\mathrm{Hba})\left(\mathrm{H}_{2} \mathrm{ba}\right) \cdot 3 \mathrm{H}_{2} \mathrm{O} \leftrightarrow \mathrm{CfH}_{2}{ }^{+}+\mathrm{Hba}^{-}+\mathrm{H}_{2} \mathrm{ba}+3 \mathrm{H}_{2} \mathrm{O}
$$

The concentration of water can be considered as almost constant and, at $\mathrm{pH} \mathrm{4,} \mathrm{ciprofloxacin}$ exists almost completely in the form of a $\mathrm{CfH}_{2}{ }^{+}$cation [45]. Therefore, the minimal solubility of 2 corresponds to the maximal value of the product of equilibrium concentrations $\left[\mathrm{Hba}^{-}\right] \cdot\left[\mathrm{H}_{2} \mathrm{ba}\right]$ in the aqueous solution. It is easy to show that the minimal solubility should be observed under the condition of $\left[\mathrm{Hba}^{-}\right]=\left[\mathrm{H}_{2} \mathrm{ba}\right]$ and at $\mathrm{pH}=\mathrm{pK}_{\mathrm{a}} \approx 4$. Such equilibrium $\mathrm{pH}$ value was established immediately after the completion of crystallization 2 from the aqueous solution containing stoichiometric amounts of $\mathrm{CfH} \cdot \mathrm{HCl} \cdot \mathrm{H}_{2} \mathrm{O}, \mathrm{H}_{2}$ ba and $\mathrm{NaOH}$ (Section 2.2).

\subsection{IR spectroscopy}

In good agreement, FTIR patterns of 1-3 display the characteristic absorption bands of CfH and barbituric/thiobarbituric acid, showing their multicomponent crystalline composition (Fig. 5S). For all compounds, the resulting spectra are different from the superimposed spectra of the starting materials. These changes point out to a different set of extended hydrogen bonding interactions for the carbonyl, hydroxyl and amino groups present in the crystal structures. In the region of stretching vibrations $v(\mathrm{COOH}), v(\mathrm{C}=\mathrm{O}), v(\mathrm{NH})$ and $v\left(\mathrm{NH}^{+}\right)$, IR spectra contain a large number of bands which complicate their assignment [7]. Thus, the assignment of the IR vibrational bands to the corresponding normal modes is based on [49-51]. The very broad bands in the 3600-3400 $\mathrm{cm}^{-1}$ region can be assigned to the stretching modes of $\mathrm{NH}$ and $\mathrm{OH}$ groups in $\mathrm{CfH}_{2}{ }^{+}, \mathrm{Htba}^{-}$and $\mathrm{Hba}^{-}$ions. The absorption bands at $1709 \mathrm{~cm}^{-1}$ for $\mathbf{1}, 1679 \mathrm{~cm}^{-1}$ for 2 and 1686 $\mathrm{cm}^{-1}$ for 3 are attributed to the $v(\mathrm{COOH})$ vibrations in the $\mathrm{CfH}_{2}{ }^{+}$cation $[9,51]$. The $\mathrm{NH}$ group of the piperazine ring was protonated in the crystalline compounds, and it is represented by the occurrence of medium intensity bands in the $2400-2700 \mathrm{~cm}^{-1}$ region [9]. These data suggest the salt formation by a proton transfer from the barbituric/thiobarbituric acid to $\mathrm{CfH}$. In the IR spectra of $\mathrm{H}_{2} \mathrm{ba}$, the highest frequency band at $1752 \mathrm{~cm}^{-1}$ is associated with the 4,6-CO symmetric vibration $v_{\mathrm{s}}(\mathrm{C}=\mathrm{O})[36,50]$. In the IR spectra of 2 , it is observed at $1722 \mathrm{~cm}^{-1}$, which agrees with the presence of the neutral $\mathrm{H}_{2}$ ba molecule, i.e. with the formation of a salt co-crystal. Therefore, infrared spectroscopy gave the evidence of the salt formation in $\mathbf{1}, \mathbf{3}$ and the salt cocrystal formation in 2.

\subsection{Thermal decomposition}


The thermal decomposition of $\mathbf{1}$ starts at $\sim 55^{\circ} \mathrm{C}$ by a loss of crystal water molecules, and it is accompanied by the endoeffect at $92.6{ }^{\circ} \mathrm{C}$ (Fig. 6S). The water removal is confirmed by the IR spectroscopic analysis of released gases. In the range from $\sim 150{ }^{\circ} \mathrm{C}$ to $\sim 270{ }^{\circ} \mathrm{C}$, the sample mass is nearly persistent, and the mass lost $(\Delta \mathrm{m})$ at $150{ }^{\circ} \mathrm{C}(9.2 \%)$ almost coincides with that calculated at the assumption of three water molecules release $(10.2 \%)$. The average value of the $\mathrm{CfH}$ melting temperature is equal to $270.0^{\circ} \mathrm{C}[52,53]$, and $\mathrm{H}_{2}$ tba melts with the decomposition at $250.6{ }^{\circ} \mathrm{C}$ [54]. Thus, compound $\mathbf{1}$ is thermally more stable than $\mathrm{H}_{2}$ tba. The melting accompanied by the oxidation of $\mathbf{1}$ occurred at $\mathrm{T}>270{ }^{\circ} \mathrm{C}$, and the mass of the sample decreased rapidly in accordance to the mean TG curve. These transformations are accompanied by the endoeffect at $288.2{ }^{\circ} \mathrm{C}$ and mild exo-effect above $325{ }^{\circ} \mathrm{C}$. According to the IR spectroscopic analysis of the gases evolved during thermolysis, $\mathrm{H}_{2} \mathrm{O}, \mathrm{CO}_{2}, \mathrm{NH}_{3}$ and $\mathrm{SO}_{2}$ are formed.

In 2 , the crystal water loss starts at $\sim 50{ }^{\circ} \mathrm{C}$ and it is accompanied by the endoeffects at 70.2 ${ }^{\circ} \mathrm{C}$ and $101.3{ }^{\circ} \mathrm{C}$ (Fig. 7S). Over the range from $\sim 150{ }^{\circ} \mathrm{C}$ to $\sim 250{ }^{\circ} \mathrm{C}$, the mass of the sample is practically unchanged, and the mass lost $(\Delta \mathrm{m})$ at $150{ }^{\circ} \mathrm{C}(7.6 \%)$ almost coincides with that calculated assuming the three water molecules release (8.4\%). The sample 2 melting is accompanied by the oxidation occurred at $\mathrm{T}>250{ }^{\circ} \mathrm{C}$, and the sample mass decreased rapidly at $\mathrm{T}>275{ }^{\circ} \mathrm{C}$ according to the mean TG curve. $\mathrm{H}_{2}$ ba melts with the decomposition at $245.0^{\circ} \mathrm{C}$ [10], i.e. compound $\mathbf{2}$ is more thermally stable than $\mathrm{H}_{2}$ ba. The oxidative decomposition of anhydrous organic residue is accompanied by a weak endo effect at $288.2{ }^{\circ} \mathrm{C}$, strong exo-effect at $331.3{ }^{\circ} \mathrm{C}$ and emission of gaseous $\mathrm{CO}_{2}, \mathrm{H}_{2} \mathrm{O}$ and $\mathrm{NH}_{3}$.

Both TG and DSC curves of $\mathbf{3}$ indicated one-step dehydration which is accompanied by the endo effect at $100.7^{\circ} \mathrm{C}$ (Fig. 8S). This is confirmed by the results of evolved gases IR spectroscopic analysis. The dehydration stage in the range of $70-130^{\circ} \mathrm{C}$ showed the weight loss $(\Delta \mathrm{m})$ equal to $2.9 \%$, but this value is lower than the calculated weight loss estimated under the assumption of total dehydration $\left(-\mathrm{H}_{2} \mathrm{O}, \Delta \mathrm{m}_{\text {theor }}=3.6 \%\right)$. The underestimated $\Delta \mathrm{m}$ values for dehydration 1-3 are probably related to the samples partial dehydration in the air. The dehydration of $\mathbf{3}$ is accompanied by the endoeffect at $100.7^{\circ} \mathrm{C}$. According to TG curves, the mass of sample 3 remains unchanged up to $\sim 275^{\circ} \mathrm{C}$ (Fig. $8 \mathrm{~S}$ ) and, then, it follows by oxidative decomposition with the gaseous $\mathrm{H}_{2} \mathrm{O}, \mathrm{CO}_{2}, \mathrm{NH}_{3}$ emissions. Similarly to $\mathbf{2}$, compound $\mathbf{3}$ is more thermal stable than $\mathrm{H}_{2}$ ba.

Thus, the TG-DSC data confirm that compounds 1-3 are hydrates and the water contents approximately correspond to the established chemical compositions.

\section{Conclusions}


$\mathrm{CfH}$ crystallization with 2-thiobarbituric and barbituric acids resulted in the isolation of a new salt co-crystal (2) and two salts $(\mathbf{1 , 3})$. The salt co-crystal is obtained in the region where the concentrations of ionized and nonionized $\mathrm{H}_{2}$ ba species are close so that both species can crystallize out. There are two intramolecular hydrogen bonds $\mathrm{C}-\mathrm{H} \cdots \mathrm{F}, \mathrm{O}-\mathrm{H} \cdots \mathrm{O}$ (Fig. 2) and numerous intermolecular hydrogen bonds $\mathrm{N}-\mathrm{H} \cdots \mathrm{O}, \mathrm{O}-\mathrm{H} \cdots \mathrm{O}$ in the structures of 1-3 (Fig. 3, Table 2). The dominant hydrogen bonding is the $\mathrm{N}-\mathrm{H} \cdots \mathrm{O}$ interaction, which leads to a centrosymmetric synthon $\mathrm{R}_{2}^{2}(8)$ and the formation of $\mathrm{Htba}^{-}$pairs in $\mathbf{1}$ and the infinite chains of $\mathrm{Hba}^{-}$ions in 2-3. The ciprofloxacinium cation has six potentially strong hydrogen bond acceptors and only two strong hydrogen bond donors ( $\mathrm{N}$ atom in $\mathrm{NH}_{2}{ }^{+}$and $\mathrm{O}$ atom in $\mathrm{COOH}$ ) (Fig. 1). However, the carbonyl and carboxyl groups of $\mathrm{CfH}_{2}{ }^{+}$are involved in a strong intramolecular hydrogen bond $\mathrm{O} 3-\mathrm{H} \cdots \mathrm{O} 1$ and, consequently, the $\mathrm{O} 3-\mathrm{H}$ group does not form a strong intermolecular hydrogen bond. Therefore, similar to structures 1-3, the self-association of fluoroquinolones with participation of $\mathrm{O} 3-\mathrm{H}$ group seems unlikely in other compounds. Water molecules stabilize crystal structures 1-3 by forming a diverse arrangement of supramolecular heterosynthons. The self-association of $\mathrm{Htba}^{-} / \mathrm{Hba}^{-}$ions and the interaction of complementary $\mathrm{Hba}^{-}$and $\mathrm{H}_{2}$ ba also stabilize the crystal structures of 1-3 (Fig. 3). In the $\mathrm{O}=\mathrm{C}_{4}-\mathrm{C}_{5} \mathrm{H}-\mathrm{C}_{6}=\mathrm{O}$ group of $\mathrm{Hba}^{-}$and $\mathrm{Htba}^{-}$anions, the charge delocalization is observed (Table 1S). Structures 1-3 are stabilized by $\pi-\pi$ interactions between $\mathrm{CfH}_{2}{ }^{+}$ions joining them in pairs (Table 2S, Figure $4 \mathrm{~S}$ ).

\section{Supplementary data}

The crystallographic data (excluding structure factors) for the structural analysis have been deposited with Cambridge Crystallographic Data Centre ((1) - CCDC 1544127; (2) CCDC 1544128; (3) - CCDC 1544129). The information may be obtained free of charge from The Director, CCDC, 12 Union Road, Cambridge CB2 1EZ, UK (Fax: +44(1223)336-033, Email: deposit@ccdc.cam.ac.uk, or www: www.ccdc.cam.ac.uk).

\section{Acknowledgements}

The study was carried out within the public task of the Ministry of Education and Science of the Russian Federation to the Siberian Federal University (4.7666.2017/BP) in 2017-2019. The reported study was funded by RFBR according to research projects 16-52-48010 and 17-5253031. Also, the work was supported by Act 211, Government of the Russian Federation, contract 02.A03.21.0011 and by the Ministry of Education and Science of the Russian Federation (4.1346.2017/PP). The X-ray data from single crystals were obtained with the use of the analytical equipment from the SB RAS Krasnoyarsk Center of collective use. 


\section{References}

[1] L. A. Mitscher, Chem. Rev. 2005, 105(2), 559.

[2] L. L. Shen, L. A. Mitscher, P. N. Sharma, T. J. ODDonnel, D. W. T. Chu, C. S. Cooper, T. Rosen, A. G. Pernet, Biochem. 1989, 28, 3886.

[3] C. S. Prabodh, J. Ankit, J. Sander. Acta Pol. Pharm-Drug Des. 2009, 66, 587.

[4] J. S. Reddy, S. V. Ganesh, R. Nagalapalli, R. Dandela, K. A. Solomon, K. A. Kumar, N. R. Goud, A. J. Nangia, Pharm. Sci. 2011, 100, 3160.

[5] L. Mafra, S. M. Santos, R. Siegel, I. Alves, F. A. Almeida Paz, D. Dudenko, H. W. Spiess, Am.Chem.Soc. 2012, 134, 71.

[6] D. L. Ross, C. M. Riley, Int. J. Pharm. 1990, 63, 237.

[7] I. Turel, Coord. Chem. Rev., 2002, 232, 27.

[8] R. Chadha, P. Singh, S. Khullarand, S. K. Mandal, Cryst. Growth Des., 2016, 16(9), 4960.

[9] K. J. Paluch, T. McCabe, H. Müller-Bunz, O. I. Corrigan, A. M. Healyand, L. Tajber, Mol. Pharmaceutics, 2013, 10(10), 3640.

[10] M. R. Chierotti, K. Gaglioti, R. Gobetto. D. Braga, F. Grepioni, L. Maini, CrystEngComm. 2013, 15, 7598 .

[11] S. Cherukuvada, R. Kaur, T. N. G. Row, CrystEngComm., 2016. DOI: 10.1039/c6ce1835a

[12] D. Braga, F. Grepioni, G. I. Lampronti, L. Maini, A. Turrina, Cryst. Growth Des., 2011, 11(12), 5621.

[13] Ö. Almarsson, M. J. Zaworotko, Chem. Commun., 2004, 17, 1889.

[14] G. P. Stahly, Cryst. Growth Des., 2009, 9, 4212.

[15] E. N. Padeiskaya, Prevention, Diagnosis, and Pharmacotherapy of Some Infectious Diseases, Bioinform, Moscow, 2002 (in Russian).

[16] K. T. Mahmudov, M. N. Kopylovich, A. M. Maharramov, M. M. Kurbanova, A. V. Gurbanov, A. J. L. Pombeiro, Coord. Chem. Rev., 2014, 265, 1.

[17] M. Gryl, K. Stadnicka, Acta Crystallogr. E, 2011, 67, m571.

[18] N. N. Golovnev, M. S. Molokeev, I. V. Sterkhova, I. I. Golovneva, J. Struct. Chem., 2016, 57(6), 1266.

[19] Cambridge Structural Database, Version 5.37, Univ. of Cambridge, Cambridge, UK, 2015.

[20] G. M. Sheldrick, Acta Cryst. A, 2008, 64, 112.

[21] PLATON - A Multipurpose Crystallographic Tool. Utrecht University, Utrecht, The Netherlands, 2008.

[22] K. Brandenburg, M. Berndt, DIAMOND - Visual Crystal Structure Information System CRYSTAL IMPACT, Postfach 1251, D-53002 Bonn

[23] N. N. Golovnev, M. S. Molokeev, Russ. J. Inorg. Chem., 2013, 58(10), 1193. 
[24] N. N. Golovnev, M. S. Molokeev, I. V. Sterkhova, V. V. Atuchin, M. Y. Sidorenko, J. Coord. Chem., 2016, 69(21), 3219.

[25] N. N. Golovnev, M. S. Molokeev, and M. Y. Belash, J. Struct. Chem., 2013, 54(3), 566.

[26] N. N. Golovnev, M. S. Molokeev, S. N. Vereshchagin, and V. V. Atuchin, J. Coord. Chem., 2013, 66(23), 4119.

[27]. N. Golovnev, M. Molokeev, Acta Cryst. C, 2013, 69(7), 704.

[28] N. N. Golovnev, M. S. Molokeev, S. N. Vereshchagin, V. V. Atuchin, M. Y. Sidorenko, M. S. Dmitrushkov, Polyhedron, 2014, 70, 71.

[29] N. N. Golovnev, M. S. Molokeev, Russ. J. Inorg. Chem., 2014, 59(2), 72.

[30] N. N. Golovnev, M. S. Molokeev, Russ. J. Coord. Chem., 2014, 40(9), 648.

[31] N. N. Golovnev, M. S. Molokeev, J. Struct. Chem., 2014, 55(1), 125.

[32] V. A. Blatov; A. P. Shevchenko; D. M. Proserpio. Crystal Growth \& Design., 2014, 14, 3576.

[33] H. C. Garcia, R. Diniz, M. I. Yoshida, L. F. C. de Oliveira, CrystEngComm., 2009, 11, 881.

[34] H. C. Garcia, R. Diniz, M. I. Yoshida, L. F. C. de Oliveira, J. Mol. Struct., 2010, 978, 79.

[35] H. C. Garcia, M. T. C. Camposa, H. G. M. Edwards , L. F. C. de Oliveira, Vib. Spectrosc., 2016, 86, 134.

[36] H. C. Garcia, F. B. de Almeida , R. Diniz, M. I. Yoshida, L. F. C. de Oliveira, J. Coord. Chem., 2011, 64, 1125.

[37] T. C. Lewis, D. A. Tocher, S. L. Price, Cryst. Growth Des., 2004, 4(5), 979.

[38] D. Braga, F. Grepioni, L. Maini, S. Prosperi, R. Gobetto, M. R. Chierotti, Chem. Comm., 2010, 46, 7715.

[39] N. N. Golovnev, M. S. Molokeev, S. N. Vereshchagin, I. V. Sterkhova, V. V. Atuchin, Polyhedron, 2015, 85, 493.

[40] M. S. Molokeev, N. N. Golovnev, S. N. Vereshchagin, V. V. Atuchin, Polyhedron, 2015, $98,113$.

[41] N. N. Golovnev, M. S. Molokeev, A. S. Samoilo, V. V. Atuchin, J. Coord. Chem., 2016, 69(6), 957.

[42] N. N. Golovnev, M. S. Molokeev, M. A. Lutoshkin, Russ. J. Inorg. Chem., 2015, 60(5), 572.

[43] N. N. Golovnev, M. S. Molokeev, I. I. Golovneva, Russ. J. Coord. Chem., 2015, 41(5), 300.

[44] S. L. Childs, P. Stahly, A. Park, Mol. Pharmaceutics, 2007, 4(3), 323.

[45] V. M. Nurchi, G. Crisponi, J. I. Lachowicz, M. A. Zoroddu, M. Peana, S. Medici, D. Veclani, M. Tolazzi, A. Melchior, Eur. J. Pharm. Sci., 2016, 93, 381. 
[46] E. Mendez, M. F. Cerda, J. S. Gancheff, J. Torres, C. Kremer, J. Castiglioni, M. Kieninger, O. N. Ventura, J. Phys. Chem. C, 2007, 111(8), 3369.

[47] D. Braga, M. Cadoni, F. Grepioni, L.Maini, K. Rubini, CrystEngComm., 2006, 8, 756.

[48] D. Braga, F. Grepioni, L. Maini, G.I. Lampronti, D. Capucci and C. Cuocci, CrystEngComm., 2012, 14, 3521.

[49] N. A. Smorygo, B. A. Ivin, Khim. Geterotsikl. Soedin., 1975, 10, 1402.

[50] J. T. Bojarski, J. L. Mokrosz, H. J. Barton, M. H. Paluchowska, Adv. Heterocycl. Chem., 1985, 38, 229.

[51] V. L. Dorofeev, Pharmaceutical Chemistry Journal, 2004, 38(12), 693.

[52] G. P. Vitorino, N. R. Sperandeo, M. R. Caira, M. R. Mazzieri, Cryst. Growth Des., 2013, 13,1050 .

[53] S. V. Blokhina, A. V. Sharapova, M. V. Ol'khovich, T. V. Volkova, G. L. Perlovich, Eur. J. Pharm. Sci., 2016, 93, 29.

[54] N. N. Golovnev, M. S. Molokeev, L. S. Tarasova, V. V. Atuchin, N. I. Vladimirova, J. Mol. Struct., 2014, 1068, 216. 
Table 1. (1-3) crystal structure parameters

\begin{tabular}{|c|c|c|c|}
\hline Single crystal & $\mathrm{CfH}_{2}(\mathrm{Htba}) \cdot 3 \mathrm{H}_{2} \mathrm{O}(\mathbf{1})$ & $\mathrm{CfH}_{2}(\mathrm{Hba})\left(\mathrm{H}_{2} \mathrm{ba}\right) \cdot 3 \mathrm{H}_{2} \mathrm{O}(\mathbf{2})$ & $\mathrm{CfH}_{2}(\mathrm{Hba}) \cdot \mathrm{H}_{2} \mathrm{O}(\mathbf{3})$ \\
\hline Moiety formula & $\mathrm{C}_{21} \mathrm{H}_{28} \mathrm{FN}_{5} \mathrm{O}_{8} \mathrm{~S}$ & $\mathrm{C}_{25} \mathrm{H}_{32} \mathrm{FN}_{7} \mathrm{O}_{12}$ & $\mathrm{C}_{21} \mathrm{H}_{24} \mathrm{FN}_{5} \mathrm{O}_{7}$ \\
\hline Dimension (mm) & $0.15 \times 0.07 \times 0.02$ & $0.25 \times 0.25 \times 0.12$ & $0.30 \times 0.02 \times 0.02$ \\
\hline Color & Pale yellow & Pale yellow & Colourless \\
\hline Molecular weight & 529.54 & 641.57 & 477.45 \\
\hline Temperature $(\mathrm{K})$ & 150 & 150 & 293 \\
\hline Space group, $Z$ & $P-1,2$ & $P-1,2$ & $P 2_{1} / c, 4$ \\
\hline$a(\AA)$ & $10.640(2)$ & $10.352(2)$ & $10.2756(7)$ \\
\hline$b(\AA)$ & $10.710(2)$ & $10.789(2)$ & $18.843(2)$ \\
\hline$c(\AA)$ & $11.476(2)$ & $13.440(3)$ & $12.049(1)$ \\
\hline$\alpha\left(^{\mathrm{o}}\right)$ & $68.64(3)$ & $72.53(3)$ & 90 \\
\hline$\beta\left(^{\circ}\right)$ & $78.31(3)$ & $82.41(3)$ & $113.364(2)$ \\
\hline$\gamma\left({ }^{\circ}\right)$ & $84.37(3)$ & $78.73(3)$ & 90 \\
\hline$V\left(\AA^{3}\right)$ & $1192.2(5)$ & $1399.8(6)$ & $2141.8(3)$ \\
\hline$\rho_{\text {calc }}\left(\mathrm{g} / \mathrm{cm}^{3}\right)$ & 1.475 & 1.522 & 1.481 \\
\hline$\mu\left(\mathrm{mm}^{-1}\right)$ & 0.201 & 0.127 & 0.118 \\
\hline Reflections measured & 13762 & 15702 & 10930 \\
\hline Reflections independent & 5464 & 6407 & 4378 \\
\hline Reflections with $F>4 \sigma(F)$ & 2920 & 4653 & 1950 \\
\hline $2 \theta_{\max }\left(^{\circ}\right)$ & 55.08 & 55.04 & 52.80 \\
\hline$h, k, l$ - limits & $\begin{array}{c}-13 \leq h \leq 13 \\
-13 \leq k \leq 13 \\
-9 \leq l \leq 14\end{array}$ & $\begin{array}{c}-13 \leq h \leq 10 \\
-13 \leq k \leq 12 \\
-17 \leq l \leq 17\end{array}$ & $\begin{array}{c}-10 \leq h \leq 12 \\
-23 \leq k \leq 19 \\
-15 \leq l \leq 15\end{array}$ \\
\hline$R_{\text {int }}$ & 0.0773 & 0.033 & 0.065 \\
\hline The weighed refinement of & $w=1 /\left[\sigma^{2}\left(F_{\mathrm{o}}^{2}\right)+(0.0472\right.$ & $w=1 /\left[\sigma^{2}\left(F_{\mathrm{o}}^{2}\right)+(0.0573 P)^{2}+\right.$ & $w=1 /\left[\sigma^{2}\left(F_{\mathrm{o}}^{2}\right)+(0.055\right.$ \\
\hline$F^{2}$ & $\left.P)^{2}\right]$ & $0.2036 P]$ & $\left.7 P)^{2}\right]$ \\
\hline No. of refinement parameters & 346 & 427 & 316 \\
\hline$R 1\left[F_{\mathrm{o}}>4 \sigma\left(F_{\mathrm{o}}\right)\right]$ & 0.0593 & 0.0433 & 0.0587 \\
\hline$w R 2$ & 0.1052 & 0.1046 & 0.1068 \\
\hline Goof & 0.949 & 1.013 & 0.932 \\
\hline$\Delta \rho_{\max }\left(\mathrm{e} / \AA^{3}\right)$ & 0.307 & 0.323 & 0.180 \\
\hline$\Delta \rho_{\min }\left(\mathrm{e} / \AA^{3}\right)$ & -0.340 & -0.273 & -0.243 \\
\hline$(\Delta / \sigma)_{\max }$ & 0.001 & 0.002 & 0.000 \\
\hline
\end{tabular}


Table 2. Hydrogen-bond geometry in (1-3) structures $\left(\AA{ }^{\circ}\right)$.

\begin{tabular}{ccccccc}
\hline $\mathrm{D}-\mathrm{H}$ & $\mathrm{d}(\mathrm{D}-\mathrm{H})$ & $\mathrm{d}(\mathrm{H} \cdots \mathrm{A})$ & $\angle \mathrm{D}-\mathrm{H} \cdots \mathrm{A}$ & $\mathrm{D} \cdots \mathrm{A}$ & $\mathrm{A}$ & Transformation for A atom \\
\hline O3-H3 & $0.90(3)$ & $1.70(3)$ & $151(3)$ & $2.522(4)$ & $\mathrm{O} 1$ & $\mathrm{x}, \mathrm{y}, \mathrm{z}$ \\
$\mathrm{C} 1-\mathrm{H} 01 \mathrm{~A}$ & 0.97 & 2.16 & 128 & $2.861(4)$ & $\mathrm{F}$ & $\mathrm{x}, \mathrm{y}, \mathrm{z}$ \\
$\mathrm{N} 1-\mathrm{H} 0 \mathrm{~A}$ & 0.89 & 2.01 & 156 & $2.843(3)$ & $\mathrm{O} 2 \mathrm{~W}$ & $1+\mathrm{Htba}) \cdot 3 \mathrm{H}_{2} \mathrm{O}(\mathbf{1})$ \\
$\mathrm{N} 1 \mathrm{~B}-\mathrm{H} 1 \mathrm{~B}$ & 0.86 & 1.89 & 168 & $2.734(4)$ & $\mathrm{O} 2 \mathrm{~B}$ & $2-\mathrm{x}, 1-\mathrm{y}, 1-\mathrm{z}$ \\
$\mathrm{N} 1-\mathrm{H} 0 \mathrm{~B}$ & 0.89 & 1.95 & 169 & $2.827(3)$ & $\mathrm{O} 1 \mathrm{~W}$ & $1-\mathrm{x}, 1-\mathrm{y}, 1-\mathrm{z}$ \\
$\mathrm{N} 3 \mathrm{~B}-\mathrm{H} 3 \mathrm{~B}$ & 0.86 & 2.42 & 168 & $3.270(2)$ & $\mathrm{S}$ & $1-\mathrm{x}, 1-\mathrm{y}, 1-\mathrm{z}$ \\
$\mathrm{O} 1 \mathrm{~W}-\mathrm{H} 11 \mathrm{~W}$ & $0.84(2)$ & $2.09(2)$ & $169(3)$ & $2.918(3)$ & $\mathrm{O} 3 \mathrm{~W}$ & $1-\mathrm{x}, 2-\mathrm{y}, 1-\mathrm{z}$ \\
$\mathrm{O} 1 \mathrm{~W}-\mathrm{H} 12 \mathrm{~W}$ & $0.89(3)$ & $1.86(3)$ & $166(3)$ & $2.728(3)$ & $\mathrm{O} 2 \mathrm{~B}$ & $1+\mathrm{x}, \mathrm{y}, \mathrm{z}$ \\
$\mathrm{O} 2 \mathrm{~W}-\mathrm{H} 21 \mathrm{~W}$ & $0.91(3)$ & $1.91(3)$ & $156(3)$ & $2.762(4)$ & $\mathrm{O} 2$ & $\mathrm{x},-1+\mathrm{y}, \mathrm{z}$ \\
$\mathrm{O} 2 \mathrm{~W}-\mathrm{H} 22 \mathrm{~W}$ & $0.89(3)$ & $1.96(3)$ & $168(3)$ & $2.834(3)$ & $\mathrm{O} 3 \mathrm{~W}$ & $1-\mathrm{x}, 1-\mathrm{y}, 1-\mathrm{z}$ \\
$\mathrm{O} 3 \mathrm{~W}-\mathrm{H} 31 \mathrm{~W}$ & $0.85(3)$ & $2.03(3)$ & $156(3)$ & $2.829(3)$ & $\mathrm{O} 1 \mathrm{~B}$ & $1-\mathrm{x}, 2-\mathrm{y}, 1-\mathrm{z}$ \\
$\mathrm{O} 3 \mathrm{~W}-\mathrm{H} 32 \mathrm{~W}$ & $0.92(3)$ & $1.84(3)$ & $171(3)$ & $2.756(3)$ & $\mathrm{O} 1 \mathrm{~B}$ & $\mathrm{x}, \mathrm{y}, \mathrm{z}$ \\
\hline
\end{tabular}

\begin{tabular}{ccccccc}
\hline O3-H3 & $0.87(2)$ & $1.70(2)$ & $160(2)$ & $2.532(2)$ & O1 & x, y, z \\
C1-H01B & 0.97 & 2.22 & 125 & $2.894(2)$ & $\mathrm{F}$ & $\mathrm{x}, \mathrm{y}, \mathrm{z}$ \\
$\mathrm{N} 1-\mathrm{H} 0 \mathrm{~A}$ & 0.89 & 1.84 & 172 & $2.727(2)$ & $\mathrm{O} 3 \mathrm{~A}$ & $1-\mathrm{x}, 2-\mathrm{y}, \mathrm{z}$ \\
$\mathrm{N} 1-\mathrm{H} 0 \mathrm{~B}$ & 0.89 & 1.95 & 168 & $2.832(2)$ & $\mathrm{O} 2 \mathrm{~B}$ & $1+\mathrm{x}, 1+\mathrm{y}, \mathrm{z}$ \\
$\mathrm{N} 1 \mathrm{~A}-\mathrm{H} 1 \mathrm{~A}$ & 0.86 & 2.10 & 169 & $2.947(2)$ & $\mathrm{O} 1 \mathrm{~B}$ & $\mathrm{x}, \mathrm{y}, \mathrm{z}$ \\
$\mathrm{N} 1 \mathrm{~B}-\mathrm{H} 1 \mathrm{~B}$ & 0.86 & 1.97 & 172 & $2.824(2)$ & $\mathrm{O} 1 \mathrm{~A}$ & $\mathrm{x}, \mathrm{y}, \mathrm{z}$ \\
$\mathrm{N} 3 \mathrm{~A}-\mathrm{H} 3 \mathrm{~A}$ & 0.86 & 2.00 & 175 & $2.860(2)$ & $\mathrm{O} 2 \mathrm{~B}$ & $1+\mathrm{x}, \mathrm{y}, \mathrm{z}$ \\
$\mathrm{N} 3 \mathrm{~B}-\mathrm{H} 3 \mathrm{~B}$ & 0.86 & 1.91 & 171 & $2.762(2)$ & $\mathrm{O} 2 \mathrm{~A}$ & $1-\mathrm{x}, \mathrm{y}, \mathrm{z}$ \\
$\mathrm{O} 1 \mathrm{~W}-\mathrm{H} 11 \mathrm{~W}$ & $0.87(2)$ & $1.90(2)$ & $173(2)$ & $2.764(2)$ & $\mathrm{O} 2 \mathrm{~A}$ & $1-\mathrm{x}, 1-\mathrm{y},-\mathrm{z}$ \\
$\mathrm{O} 1 \mathrm{~W}-\mathrm{H} 12 \mathrm{~W}$ & $0.92(2)$ & $1.93(2)$ & $160(2)$ & $2.805(2)$ & $\mathrm{O} 2 \mathrm{~W}$ & $-\mathrm{x}, 1-\mathrm{y},-\mathrm{z}$ \\
$\mathrm{O} 2 \mathrm{~W}-\mathrm{H} 21 \mathrm{~W}$ & $0.92(2)$ & $1.84(2)$ & $164(2)$ & $2.741(2)$ & $\mathrm{O} 1 \mathrm{~W}$ & $\mathrm{x}, 1+\mathrm{y}, \mathrm{z}$ \\
$\mathrm{O} 2 \mathrm{~W}-\mathrm{H} 22 \mathrm{~W}$ & $0.87(2)$ & $1.87(2)$ & $171(2)$ & $2.762(2)$ & $\mathrm{O} 3 \mathrm{~A}$ & $\mathrm{x}, \mathrm{y}, \mathrm{z}$ \\
$\mathrm{O} 3 \mathrm{~W}-\mathrm{H} 31 \mathrm{~W}$ & $0.90(2)$ & $2.13(2)$ & $153(2)$ & $2.965(2)$ & $\mathrm{O} 2$ & $1-\mathrm{x},-\mathrm{y}, 1-\mathrm{z}$ \\
$\mathrm{O} 3 \mathrm{~W}-\mathrm{H} 32 \mathrm{~W}$ & $0.94(2)$ & $2.08(2)$ & $169(2)$ & $3.004(2)$ & $\mathrm{O} 1$ & $\mathrm{x}, \mathrm{y}, \mathrm{z}$
\end{tabular}

\begin{tabular}{ccccccc}
\hline \multicolumn{7}{c}{$\mathrm{CfH}_{2}(\mathrm{Hba}) \cdot \mathrm{H}_{2} \mathrm{O}(3)$} \\
\hline $\mathrm{O} 2-\mathrm{H} 2$ & $0.92(3)$ & $1.63(4)$ & $156(3)$ & $2.502(4)$ & $\mathrm{O} 1$ & $\mathrm{x}, \mathrm{y}, \mathrm{z}$ \\
$\mathrm{C} 1-\mathrm{H} 01 \mathrm{~A}$ & 0.97 & 2.25 & 124 & $2.902(4)$ & $\mathrm{F}$ & $\mathrm{x}, \mathrm{y}, \mathrm{z}$ \\
$\mathrm{N} 1-\mathrm{H} 0 \mathrm{~A}$ & 0.89 & 1.83 & 168 & $2.708(3)$ & $\mathrm{O} 2 \mathrm{~A}$ & $\mathrm{x}, \mathrm{y}, \mathrm{z}$
\end{tabular}




$\begin{array}{ccccccc}\text { N1A-H1A } & 0.86 & 2.09 & 163 & 2.924(3) & \text { O1A } & 1-x, 2-y, 1-z \\ \text { N1B-H1B } & 0.86 & 1.98 & 173 & 2.831(3) & \text { O2A } & -x, 2-y, 1-z \\ \text { O1W-H11W } & 0.94(3) & 1.84(3) & 174(3) & 2.779(4) & \text { O3A } & \text { x, y, z } \\ \text { O1W-H12W } & 0.92(4) & 1.94(4) & 173(3) & 2.859(4) & \text { O2W } & -x, 1-y, 1-z\end{array}$<smiles>O=C(O)c1cn(C2CC2)c2cc(N3CCNCC3)c(F)cc2c1=O</smiles>

a)

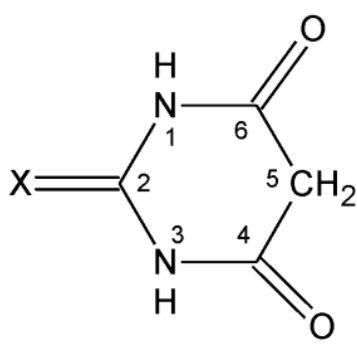

$\mathrm{X}=\mathrm{S}, \mathrm{O}$

b)

Figure 1. Schemes of ciprofloxacin (a) and barbituric acids (b): $\mathrm{X}=\mathrm{O}$ in $\mathrm{H}_{2}$ ba and $\mathrm{X}=\mathrm{S}$ in $\mathrm{H}_{2}$ tba.

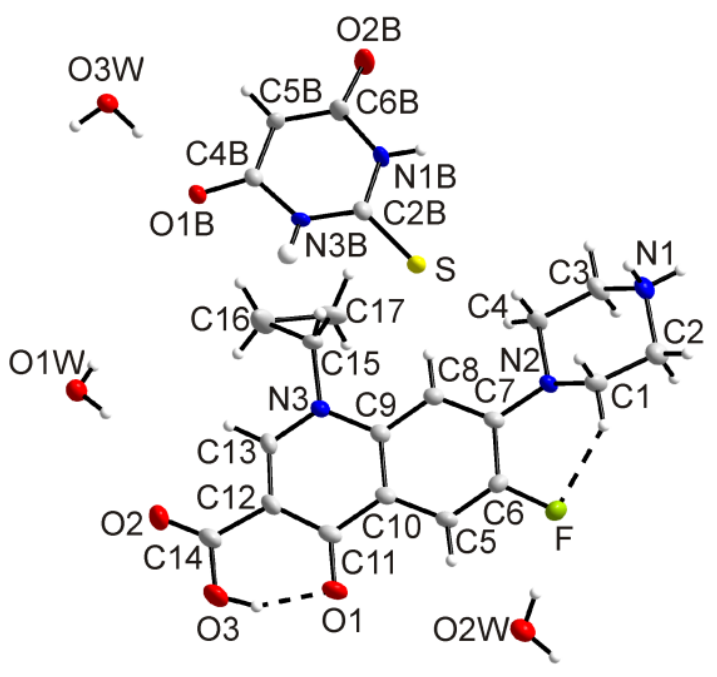

a)

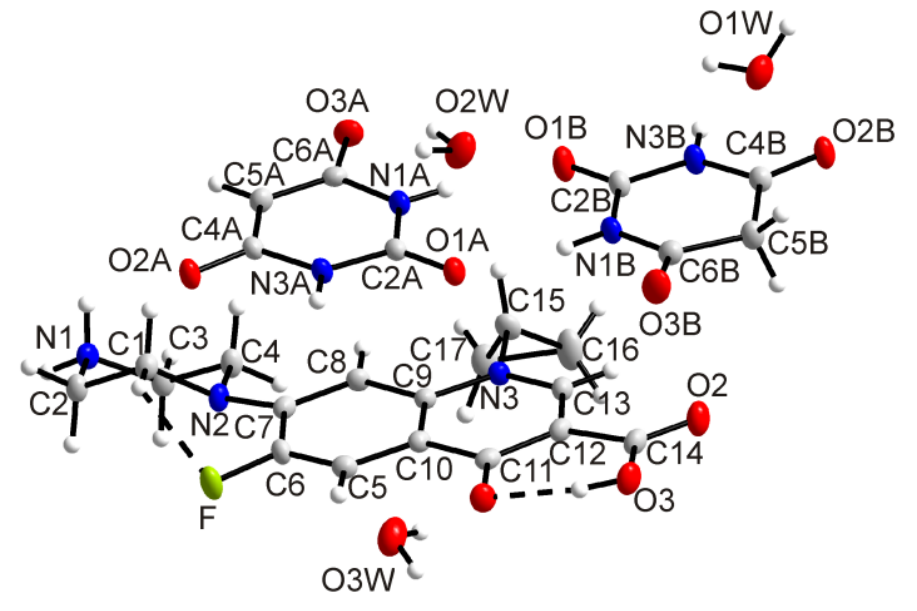

b)

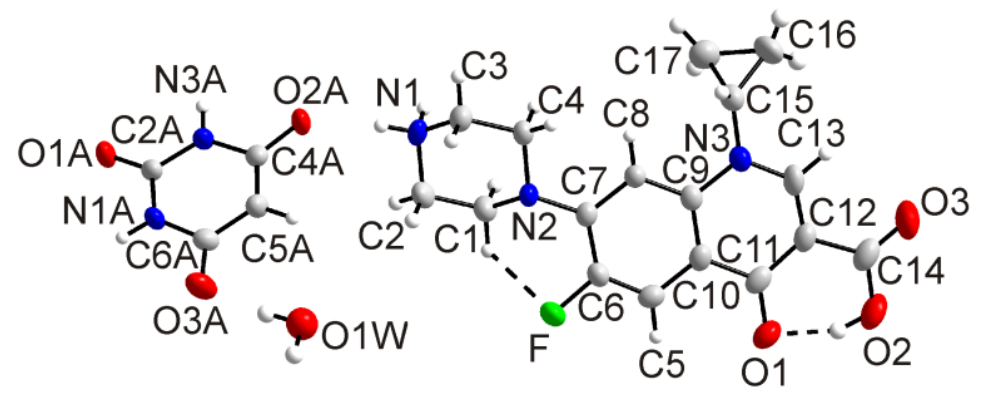

c)

Fig. 2 The asymmetric part of the unit cell: a) $\mathrm{CfH}_{2}(\mathrm{Htba}) \cdot 3 \mathrm{H}_{2} \mathrm{O}(\mathbf{1})$; b) $\mathrm{CfH}_{2}(\mathrm{Hba})\left(\mathrm{H}_{2} \mathrm{ba}\right) \cdot 3 \mathrm{H}_{2} \mathrm{O}$ (2); c) $\mathrm{CfH}_{2}(\mathrm{Hba}) \cdot \mathrm{H}_{2} \mathrm{O}(3)$. Ellipsoids are drawn at the $50 \%$ probability level, except for the hydrogen atoms represented by spheres. The intramolecular hydrogen bonds are shown with dashed lines. 


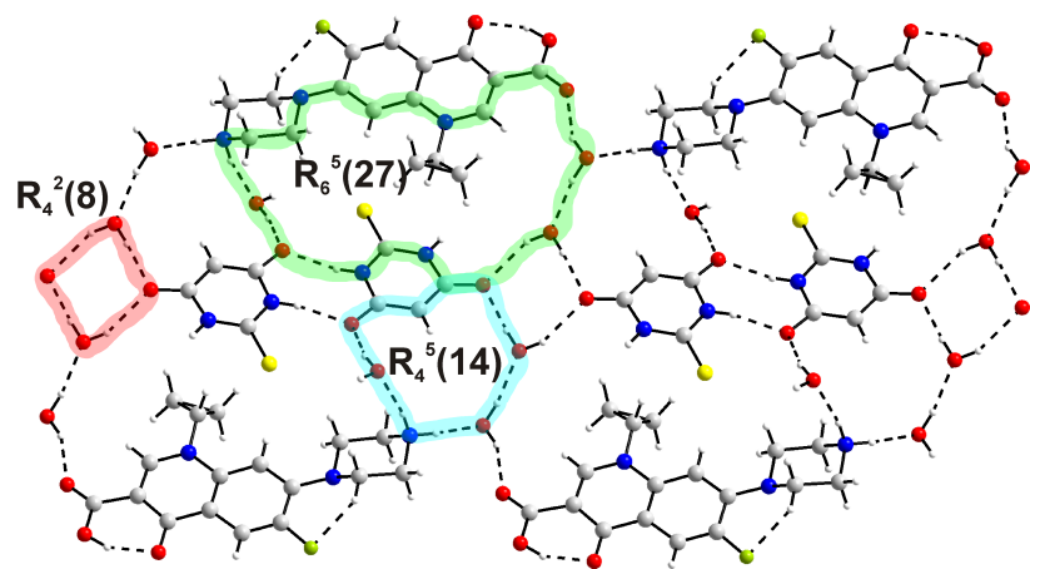

a)

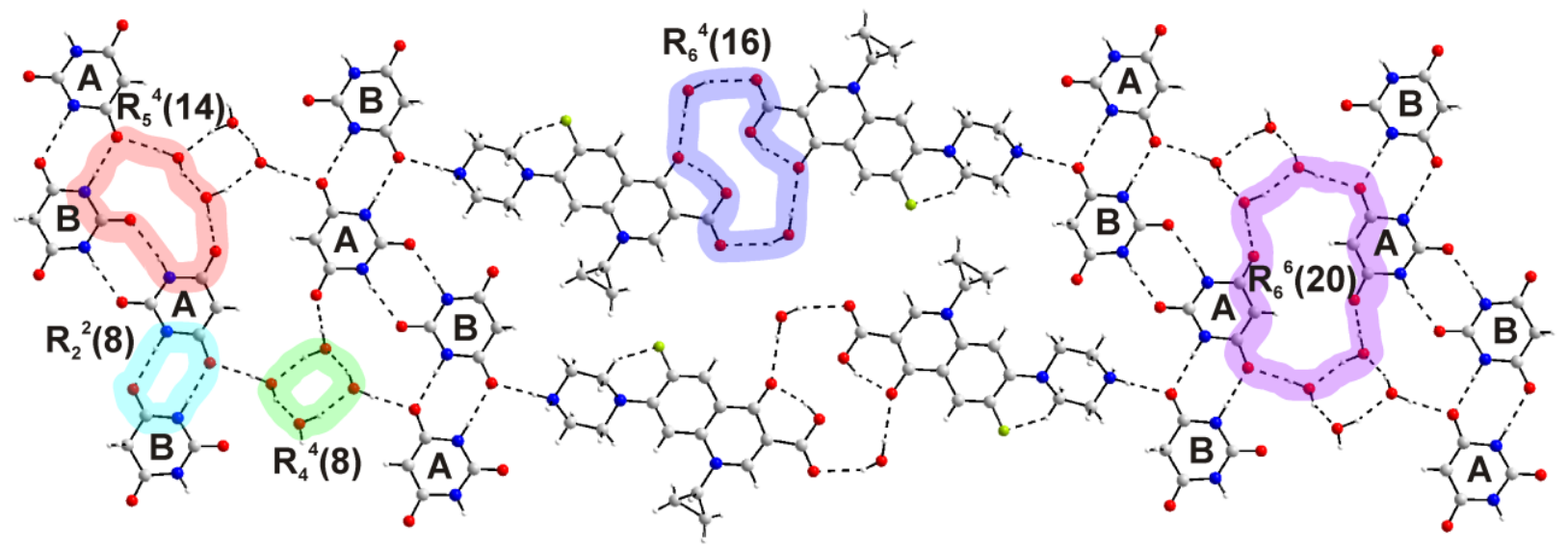

b)

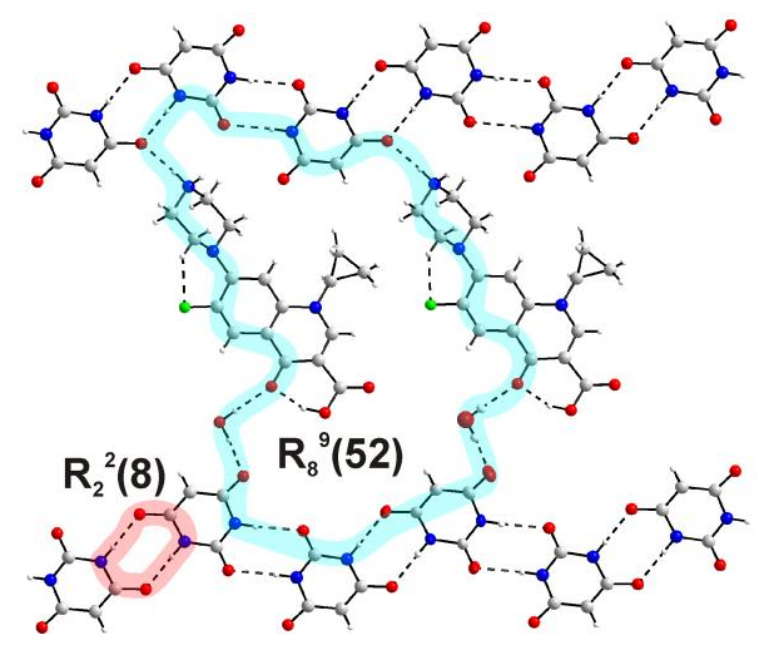

c)

Fig. 3 Hydrogen bonding in $\mathbf{1}$ (a), 2 (b) and $\mathbf{3}$ (c). The H-bonds are marked by dashed lines, the $\mathrm{H}$-bond motifs are marked by circles and broad lines. Labels A and B in 2 marked $\mathrm{Hba}^{-}$and $\mathrm{H}_{2}$ ba, respectively. 